\title{
Biliary tract external drainage increases the expression levels of heme oxygenase- 1 in rat livers
}

\author{
Lu Wang, Bing Zhao, Ying Chen, Li Ma, Er-Zhen Chen* and En-Qiang Mao*
}

\begin{abstract}
Background: Heme oxygenase-1 (HO-1) protects cells by anti-oxidation, maintaining normal microcirculation and anti-inflammatory under stress. This study investigated the effects of biliary tract external drainage (BTED) on the expression levels of $\mathrm{HO}-1$ in rat livers.

Methods: Biliary tract external drainage was performed by inserting a cannula into the bile duct. Sixty SpragueDawley rats were randomized to the following groups: sham $1 \mathrm{~h}$ group; BTED $1 \mathrm{~h}$ group; bile duct ligation (BDL) $1 \mathrm{~h}$ group; sham $6 \mathrm{~h}$ group and BTED $6 \mathrm{~h}$ group. The expression levels of HO-1 mRNA were analyzed using real-time RTPCR. The expression levels of $\mathrm{HO}-1$ were analyzed using immunohistochemistry.

Results: The expression levels of HO-1 mRNA in the liver of the BTED group increased significantly compared with the sham group 1 and $6 \mathrm{~h}$ after surgery $(p<0.05)$. The expression levels of HO- 1 in the BTED group increased significantly compared with the sham group 1 and $6 \mathrm{~h}$ after surgery. The expression levels of $\mathrm{HO}-1 \mathrm{mRNA}$ in the liver in the $\mathrm{BDL}$ group decreased significantly compared with the sham group $1 \mathrm{~h}$ after surgery $(p<0.05)$. The expression levels of $\mathrm{HO}-1$ in the BDL group decreased significantly compared with the sham group at this time.
\end{abstract}

Conclusion: Biliary tract external drainages increase the expression levels of HO-1 in the liver.

Keywords: Biliary tract external drainage, Heme oxygenase-1

\section{Background}

Heme oxygenase-1 (HO-1) protects cells by anti-oxidation, maintaining normal microcirculation and antiinflammatory under stress. Four decades of research have witnessed the HO-1 system continues to fascinate researchers across many areas of basic and clinical sciences $[1,2]$. Bilirubin may play an negative feedback on the formation of HO-1 according to this theory. We speculate that biliary tract external drainage (BTED) may induce compensatory increase in $\mathrm{HO}-1$ expression via blocking the enterohepatic circulation of bilirubin. Therefore, we explored effects of BTED on HO-1 expression in the liver.

\footnotetext{
*Correspondence: chenerzhen@hotmail.com; maoeq@yeah.net Department of Emergency Intensive Care Unit, Shanghai Ruijin Hospital,

School of Medicine, Shanghai Jiao Tong University, Shanghai 200025, China
}

\section{Methods}

Sixty adult male Sprague-Dawley rats $(250-300$ g) were purchased from the Experimental Animal Center of Ruijin Hospital. Rats were housed and fed in accordance with the guidelines of the Committee on Care and Use of Laboratory Animal Resources approved by the Shanghai Jiao Tong University Medicine School Animal Care and Ethics Committee.

After a 1-week adaption period during which food and water were available ad libitum, rats were randomly divided into 5 groups: sham $1 \mathrm{~h}$ group; BTED $1 \mathrm{~h}$ group; bile duct ligation (BDL) $1 \mathrm{~h}$ group; sham $6 \mathrm{~h}$ group and BTED $6 \mathrm{~h}$ group. Rats were fasted overnight prior to experiments, but water was available ad libitum. Rats in the BTED group were intraperitoneally anesthetized with $3 \%$ sodium pentobarbital $(0.2 \mathrm{ml} / 100 \mathrm{~g})$. Laparotomies were performed after shaving and sterilization. Bile duct 
was exposed long enough for BTED. A catheter (inner diameter $0.4 \mathrm{~mm}$; outer diameter $0.8 \mathrm{~mm}$; length $20 \mathrm{~cm}$ ) was inserted into the bile duct. The distal end of bile duct was ligated. The catheter was passed through the flank of rats to avoid bile passage into the gut and allow for the external collection of bile. In the BDL group, the bile duct was ligated. The abdomen was closed subsequently. Rats in the BDL group underwent pentobarbital anesthesia, laparotomy, bile duct ligation and suture. Rats in the sham group underwent pentobarbital anesthesia, laparotomy and suture. Twelve rats in every group were sacrificed at the point of setting time. Livers were collected.

\section{The expression levels of HO-1 messenger RNA (mRNA)} in the liver

Liver scrapings from all animals were snap frozen and stored at $-80^{\circ} \mathrm{C}$ for real-time RT-PCR. Total RNA was extracted from the liver using TRIzol reagent. Aliquots $(2 \mu \mathrm{g})$ of total RNA were used to synthesize complementary DNA (cDNA). Purity and content of RNA was determined using ultraviolet spectrophotometry. A reverse transcription reaction was conducted in a mixture containing random primers, Revert Aid Reverse Transcriptase, RNase inhibitor, and dNTPs. The PCR reaction mixture was prepared using an SYBR Premix Ex Taq with specific upstream and downstream primers. The thermal cycling conditions were $10 \mathrm{~s}$ at $95^{\circ} \mathrm{C}$ for the initial denaturation step followed by 40 cycles of $95^{\circ} \mathrm{C}$ for $5 \mathrm{~s}$ and $60^{\circ} \mathrm{C}$ for $20 \mathrm{~s}$ in a real-time PCR system (7500, ABI, Foster, USA). The mRNA levels of $\mathrm{HO}-1$ are expressed relative to the sham rats using the $\Delta \Delta \mathrm{Ct}$ method. The primers for HO-1 were $5^{\prime}$-ACCCCACCAAGTTCAAACAG- $3^{\prime}$ and $5^{\prime}$-GAGCAGGAAGGCGGT-CTTAG-3'. The primers for $\beta$-actin were $5^{\prime}$-GCGCTCGTCGTCGACAACGG-3' and 5'-GTGTGGTGCCAAATCTTCTCC-3'.

\section{Immunohistochemistry}

Samples were fixed in $4 \%$ paraformaldehyde, embedded in paraffin and sectioned at $4 \mu \mathrm{m}$. Sections were mounted onto APES-coated slides, deparaffinized, rehydrated, incubated in 3\% hydrogen peroxide to quench any endogenous peroxidase activity, and washed with distilled water and PBS for $5 \mathrm{~min}$. Sections were placed in $3 \%$ citrate buffer to repair antigens. The buffer was heated to a temperature of $92-98^{\circ} \mathrm{C}$ using a microwave and maintained at that temperature for $10 \mathrm{~min}$. The sections were cooled to room temperature. A $10 \%$ nonimmune goat serum was applied to eliminate nonspecific staining. Sections were incubated overnight at $4^{\circ} \mathrm{C}$ with optimally diluted primary antibody. Primary antibody used for immunohistochemistry was a rabbit polyclonal to HO-1 (1:200). Sections were washed with PBS and incubated with a broad-spectrum second antibody for
$30 \mathrm{~min}$, rewashed, and incubated with peroxidase-conjugated streptavidin for $15 \mathrm{~min}$. Peroxidation activity was visualized via incubation with a peroxidase substrate solution (DAB kit). Sections were counterstained with hematoxylin.

\section{Reagents}

TRIzol lysate was purchased from the Invitrogen Company (Frederick, USA), The revertAid first stand cDNA synthesis kit was purchased from the Thermo Company (Lithuania, EU), the Fluorescence quantitative RT-PCR kit was purchased from the Takara Company (Dalian, China), the HO-1 primers were synthesized by the Invitrogen Company (Shanghai, China), the anti-heme oxygenase 1 antibody was purchased from the Abcam Company (Cambridge, MA, USA), the immunohistochemistry kit was purchased from the Invitrogen Company (Frederick, USA).

\section{Statistics}

Data were analyzed using SPSS 16.0 software. All data are expressed as mean \pm SE of mean values, and results were compared using the unpaired Student's $t$ test and one-way analysis of variance followed by Tukey's test. A $p<0.05$ was considered to be statistically significant.

\section{Results}

\section{Effects of BTED on the expression levels of HO-1 mRNA} in the liver

The expression levels of HO-1 mRNA in the liver of the BTED group increased significantly compared with the sham group $1 \mathrm{~h}$ after surgery $(p<0.05)$ (Figure $1 \mathrm{a})$. The expression levels of HO-1 mRNA in the liver of the BDL group decreased significantly compared with the sham group $1 \mathrm{~h}$ after surgery $(p<0.05)$ (Figure 1a). The expression levels of HO-1 mRNA in the liver of the BTED group increased significantly compared with the sham group $6 \mathrm{~h}$ after surgery $(p<0.05)$ (Figure $1 \mathrm{~b})$.

\section{Immunohistochemistry}

The expression levels of HO-1 in the liver of the BTED group increased significantly compared with the sham group $1 \mathrm{~h}$ after surgery (Figure 2a, b). The expression levels of HO-1 in the liver of the BDL group decreased significantly compared with the sham group $1 \mathrm{~h}$ after surgery (Figure 2a, c). The expression levels of HO-1 in the liver of the BTED group increased significantly compared with the sham group $6 \mathrm{~h}$ after surgery (Figures $2 \mathrm{~d}, \mathrm{e}$ ).

\section{Discussion}

HO-1, a 32-kDa microsomal enzyme [3], catalyzes the rate-limiting step in oxidative degradation of heme to $\mathrm{CO}$, biliverdin (soon reduced to bilirubin) and iron [4]. 

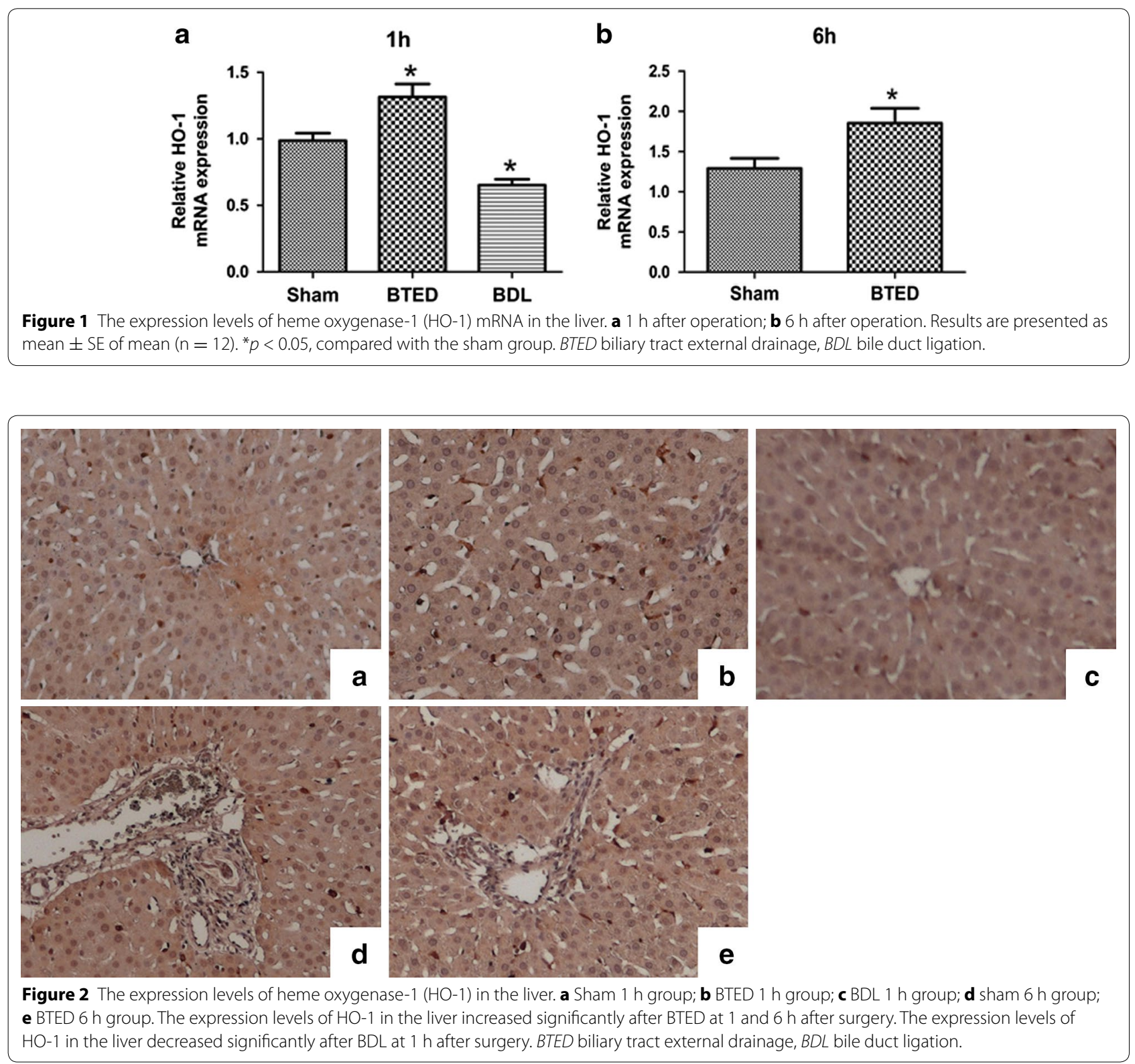

Since its discovery [5], studies have shown that HO-1 plays an important role in many modern medical disciplines, such as critical care [6-8], pulmonology [9-11], nephrology [12-14], gastroenterology [15-17], cardiology [18-20], neurology [21-23] and transplant immunology [24-26]. Sofalcone increases HO-1 in human umbilical vein endothelial cells and blocks endothelial dysfunction [27]. The polymorphism of the guanidinium thiocyanate repeats in the HO-1 promoter region is associated with the development of necrotizing acute pancreatitis [28]. Capsaicin induces HO-1 expression in kidney tissues and ameliorates cisplatin-induced renal dysfunction. Notably, the protective effects of capsaicin were completely abrogated by treatment with HO-1 inhibitor [29]. HO-1 expression protects the heart from acute injury [30].

The HO-1 system plays a vital role in anti-oxidative stress, anti-inflammation and regulation of cytokine expression. The analysis of the HO-1 gene knockout mice showed that HO-1 is an important molecule in systemic responses to stress. Endothelial cells are more susceptible to cytotoxicity induced by pro-oxidant stimuli in this case and produce more intracellular reactive oxygen species (ROS) when challenged with such stimuli [31-33]. HO-dependent protection is due to the reaction products of $\mathrm{HO}$ activity. $\mathrm{CO}$, biliverdin and iron each contribute to the restoration of cellular homeostasis under inducing 


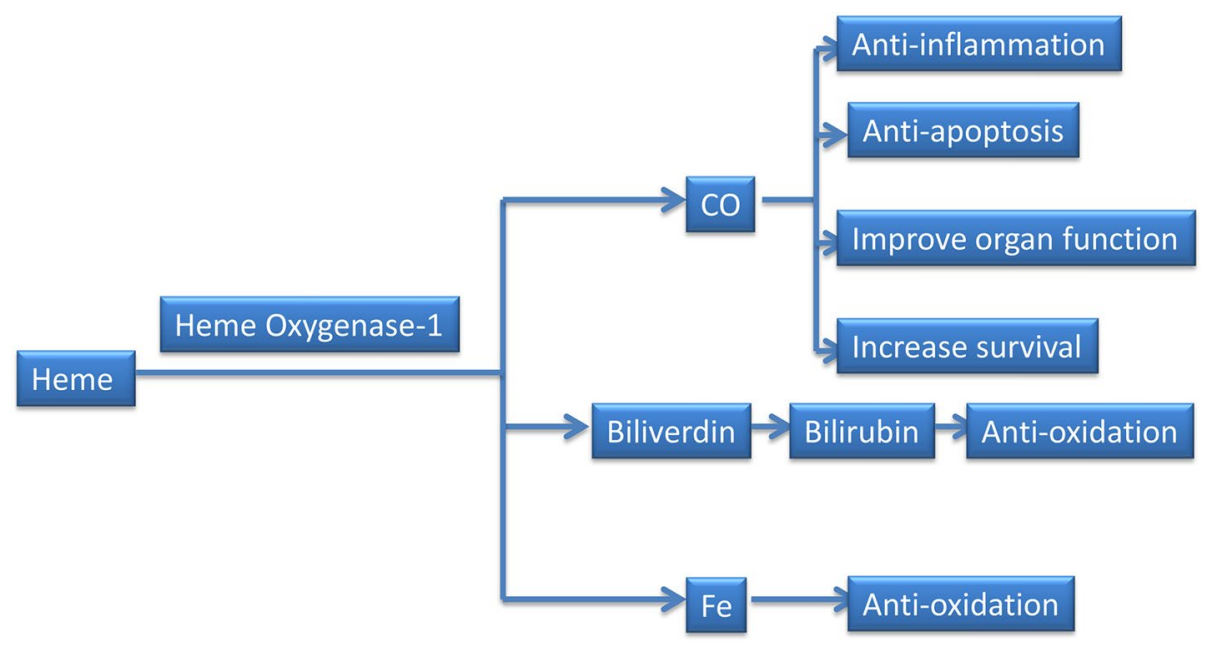

Figure 3 The three end-products of heme oxygenase-1 activity can protect cells against injury.

conditions [34, 35]. CO decreases proinflammatory cytokine production [36-39], reduces apoptosis [40-42], improves organ function [43, 44] and increases survival [45-47]. Biliverdin and bilirubin, the end bile pigments of heme degradation, protect cells against injury caused by oxidative stress in vitro $[46,48,49]$. Iron potentially acts as a catalyst of deleterious pro-oxidant reactions [50-52] (Figure 3).

Bilirubin may play a role via negative feedback on the formation of $\mathrm{HO}-1$ according to theory. We speculate that BTED may induce compensatory increases in HO-1 expression in the liver by blocking the enterohepatic circulation of bilirubin. In this research, we found that the expression levels of HO-1 in the liver of the BTED group increased significantly compared with the sham group. The expression levels of HO-1 in the liver of the BDL group decreased significantly compared with the sham group. These results demonstrate that BTED may play important roles in anti-inflammation, anti-oxidative stress and regulation of cytokine expression by increasing the expression levels of HO-1. Specific roles of BTED in the treatment of diseases require further study.

\section{Conclusion}

The expression levels of HO-1 mRNA and protein in the liver increased significantly from $1 \mathrm{~h}$ after BTED and this effect lasts for more than $6 \mathrm{~h}$. The expression levels of HO-1 mRNA and protein in the liver decreased significantly $1 \mathrm{~h}$ after BDL.

\section{Authors' contributions}

$L W, E Z C$ and EQM drafted the manuscript. LW, BZ, and YC participated in the surgical procedure. LW and BZ carried out the immunohistochemistry. LM carried out the real-time PCR. LW and YC performed the statistical analysis. EZC and EQM conceived of the study, and participated in the design of the study. All authors read and approved the final manuscript.

\section{Acknowledgements}

This research was supported by National Natural Science Foundation of China (No. 81171789). We thank the staff of Shanghai Institute of Traumatology and Orthopaedics for their technical support.

\section{Compliance with ethical guidelines}

\section{Competing interests}

The authors declare that they have no competing interests.

Received: 25 April 2015 Accepted: 30 June 2015

Published online: 22 July 2015

\section{References}

1. Janssen A, Fiebiger S, Bros H, Hertwig L, Romero-Suarez S, Hamann I et al (2015) Treatment of chronic experimental autoimmune encephalomyelitis with epigallocatechin-3-gallate and glatiramer acetate alters expression of heme-oxygenase-1. PLoS One 10:e0130251

2. Surolia R, Karki S, Kim H, Yu Z, Kulkarni T, Mirov SB et al (2015) Heme oxygenase-1 mediated autophagy protects against pulmonary endothelial cell death and development of emphysema in cadmium treated mice. Am J Physiol Lung Cell Mol Physiol. doi:10.1152/ajplung.00097

3. Verma A, Hirsch DJ, Glatt CE, Ronnett GV, Snyder SH (1993) Carbon monoxide: a putative neural messenger. Science 259:381-384

4. Christodoulides N, Durante W, Kroll MH, Schafer Al (1995) Vascular smooth muscle cell heme oxygenases generate guanylyl cyclase-stimulatory carbon monoxide. Circulation 91:2306-2309

5. Tenhunen R, Marver HS, Schmid R (1968) The enzymatic conversion of heme to bilirubin by microsomal heme oxygenase. Proc Natl Acad Sci USA 61:748-755

6. Hoetzel A, Leitz D, Schmidt R, Tritschler E, Bauer I, Loop T et al (2006) Mechanism of hepatic heme oxygenase-1 induction by isoflurane. Anesthesiology 104:101-109

7. Kim YH, Yoon DW, Kim JH, Lee JH, Lim CH (2014) Effect of remote ischemic post-conditioning on systemic inflammatory response and survival rate in lipopolysaccharide-induced systemic inflammation model. J Inflamm (Lond) 11:16

8. Zhao B, Fei J, Chen Y, Ying YL, Ma L, Song XQ et al (2014) Vitamin C treatment attenuates hemorrhagic shock related multi-organ injuries through the induction of heme oxygenase-1. BMC Complement Altern Med $14: 442$

9. Raval CM, Lee PJ (2010) Heme oxygenase-1 in lung disease. Curr Drug Targets 11:1532-1540 
10. Joo Choi R, Cheng MS, Shik Kim Y (2014) Desoxyrhapontigenin upregulates $\mathrm{Nrf2}$-mediated heme oxygenase-1 expression in macrophages and inflammatory lung injury. Redox Biol 2:504-512

11. Shu YS, Tao W, Miao QB, Zhu YB, Yang YF (2014) Improvement of ventilation-induced lung injury in a rodent model by inhibition of inhibitory kappaB kinase. J Trauma Acute Care Surg 76:1417-1424

12. Shin DH, Park HM, Jung KA, Choi HG, Kim JA, Kim DD et al (2010) The NRF2-heme oxygenase-1 system modulates cyclosporin A-induced epithelial-mesenchymal transition and renal fibrosis. Free Radic Biol Med 48:1051-1063

13. Chung S, Yoon HE, Kim SJ, Koh ES, Hong YA, Park CW et al (2014) Oleanolic acid attenuates renal fibrosis in mice with unilateral ureteral obstruction via facilitating nuclear translocation of Nrf2. Nutr Metab (Lond) 11:2

14. Chintagari NR, Nguyen J, Belcher JD, Vercellotti GM, Alayash Al (2015) Haptoglobin attenuates hemoglobin-induced heme oxygenase-1 in renal proximal tubule cells and kidneys of a mouse model of sickle cell disease. Blood Cells Mol Dis 54:302-306

15. Yoda Y, Amagase K, Kato S, Tokioka S, Murano M, Kakimoto K et al (2010) Prevention by lansoprazole, a proton pump inhibitor, of indomethacin -induced small intestinal ulceration in rats through induction of heme oxygenase-1. J Physiol Pharmacol 61:287-294

16. Takano T, Yonemitsu Y, Saito S, Itoh H, Onohara T, Fukuda A et al (2012) A somatostatin analogue, octreotide, ameliorates intestinal ischemiareperfusion injury through the early induction of heme oxygenase-1. J Surg Res 175:350-358

17. Niu X, de Graaf IA, van der Bij HA, Groothuis GM (2014) Precision cut intestinal slices are an appropriate ex vivo model to study NSAID-induced intestinal toxicity in rats. Toxicol In Vitro 28:1296-1305

18. Motawi TK, Darwish HA (2011) Abd El Tawab AM. Effects of caffeic acid phenethyl ester on endotoxin-induced cardiac stress in rats: a possible mechanism of protection. J Biochem Mol Toxicol 25:84-94

19. Lee YM, Cheng PY, Chim LS, Kung CW, Ka SM, Chung MT et al (2011) Baicalein, an active component of Scutellaria baicalensis Georgi, improves cardiac contractile function in endotoxaemic rats via induction of heme oxygenase-1 and suppression of inflammatory responses. J Ethnopharmacol 135:179-185

20. Issan Y, Kornowski R, Aravot D, Shainberg A, Laniado-Schwartzman M, Sodhi K et al (2014) Heme oxygenase-1 induction improves cardiac function following myocardial ischemia by reducing oxidative stress. PLoS One 9:e92246

21. Ogawa T, Hanggi D, Steiger HJ (2011) Treatment of experimental cerebral vasospasm by protein transduction of heme oxygenase $1(\mathrm{HO}-1)$ conjugated to a residue of 11 arginines. Acta Neurochir Suppl 112:111-113

22. Ashabi G, Khalaj L, Khodagholi F, Goudarzvand M, Sarkaki A (2014) Pre-treatment with metformin activates Nrf2 antioxidant pathways and inhibits inflammatory responses through induction of AMPK after transient global cerebral ischemia. Metab Brain Dis 30:747-754

23. Trovato Salinaro A, Cornelius C, Koverech G, Koverech A, Scuto M, Lodato F et al (2014) Cellular stress response, redox status, and vitagenes in glaucoma: a systemic oxidant disorder linked to Alzheimer's disease. Front Pharmacol 5:129

24. Buchholz BM, Masutani K, Kawamura T, Peng X, Toyoda Y, Billiar TR et al (2011) Hydrogen-enriched preservation protects the isogeneic intestinal graft and amends recipient gastric function during transplantation. Transplantation 92:985-992

25. Salahudeen AK, Yang M, Huang H, Dore S, Stec DE (2011) Fenoldopam preconditioning: role of heme oxygenase- 1 in protecting human tubular cells and rodent kidneys against cold-hypoxic injury. Transplantation 91:176-182

26. Noda K, Shigemura N, Tanaka Y, Bhama J, D'Cunha J, Kobayashi H et al (2014) Hydrogen preconditioning during ex vivo lung perfusion improves the quality of lung grafts in rats. Transplantation 98:499-506

27. Onda K, Tong S, Nakahara A, Kondo M, Monchusho H, Hirano T et al (2015) Sofalcone upregulates the nuclear factor (erythroid-derived 2)-like 2/heme oxygenase-1 pathway, reduces soluble fms-like tyrosine kinase-1, and quenches endothelial dysfunction: potential therapeutic for preeclampsia. Hypertension 65:855-862

28. Gulla A, Evans BJ, Navenot JM, Pundzius J, Barauskas G, Gulbinas A et al (2014) Heme oxygenase-1 gene promoter polymorphism is associated with the development of necrotizing acute pancreatitis. Pancreas 43:1271-1276

29. Jung SH, Kim HJ, Oh GS, Shen A, Lee S, Choe SK et al (2014) Capsaicin ameliorates cisplatin-induced renal injury through induction of heme oxygenase-1. Mol Cells 37:234-240

30. Hull TD, Bolisetty S, DeAlmeida AC, Litovsky SH, Prabhu SD, Agarwal A et al (2013) Heme oxygenase-1 expression protects the heart from acute injury caused by inducible Cre recombinase. Lab Invest 93:868-879

31. Poss KD, Tonegawa S (1997) Reduced stress defense in heme oxygenase 1-deficient cells. Proc Natl Acad Sci USA 94:10925-10930

32. Larsen R, Gozzelino R, Jeney V, Tokaji L, Bozza FA, Japiassu AM et al (2010) A central role for free heme in the pathogenesis of severe sepsis. Sci Transl Med 2:51ra71

33. Kovtunovych G, Ghosh MC, Ollivierre W, Weitzel RP, Eckhaus MA, Tisdale JF et al (2014) Wild-type macrophages reverse disease in heme oxygenase 1-deficient mice. Blood 124:1522-1530

34. Ryter SW, Alam J, Choi AM (2006) Heme oxygenase-1/carbon monoxide: from basic science to therapeutic applications. Physiol Rev 86:583-650

35. Ryter SW, Morse D, Choi AM (2007) Carbon monoxide and bilirubin: potential therapies for pulmonary/vascular injury and disease. Am J Respir Cell Mol Biol 36:175-182

36. Nakao A, Kimizuka K, Stolz DB, Seda Neto J, Kaizu T, Choi AM et al (2003) Protective effect of carbon monoxide inhalation for cold-preserved small intestinal grafts. Surgery 134:285-292

37. Kohmoto J, Nakao A, Kaizu T, Tsung A, Ikeda A, Tomiyama Ket al (2006) Low-dose carbon monoxide inhalation prevents ischemia/reperfusion injury of transplanted rat lung grafts. Surgery 140:179-185

38. Bakhautdin B, Das D, Mandal P, Roychowdhury S, Danner J, Bush K et al (2014) Protective role of HO-1 and carbon monoxide in ethanol-induced hepatocyte cell death and liver injury in mice. J Hepatol 61:1029-1037

39. Choi EK, Park HJ, Sul OJ, Rajesekaran M, Yu R, Choi HS (2015) Carbon monoxide reverses adipose tissue inflammation and insulin resistance upon loss of ovarian function. Am J Physiol Endocrinol Metab 308:621-630

40. Kaizu T, Nakao A, Tsung A, Toyokawa H, Sahai R, Geller DA et al (2005) Carbon monoxide inhalation ameliorates cold ischemia/reperfusion injury after rat liver transplantation. Surgery 138:229-235

41. Schallner N, Fuchs M, Schwer Cl, Loop T, Buerkle H, Lagreze WA et al (2012) Postconditioning with inhaled carbon monoxide counteracts apoptosis and neuroinflammation in the ischemic rat retina. PLoS One 7:e46479

42. Nikolic I, Saksida T, Mangano K, Vujicic M, Stojanovic I, Nicoletti F et al (2014) Pharmacological application of carbon monoxide ameliorates islet-directed autoimmunity in mice via anti-inflammatory and antiapoptotic effects. Diabetologia 57:980-990

43. Mazzola S, Forni M, Albertini M, Bacci ML, Zannoni A, Gentilini F et al (2005) Carbon monoxide pretreatment prevents respiratory derangement and ameliorates hyperacute endotoxic shock in pigs. FASEB J 19:2045-2047

44. Yao L, Wang P, Chen M, Liu Y, Zhou L, Fang X et al (2014) Carbon monoxide-releasing molecules attenuate postresuscitation myocardial injury and protect cardiac mitochondrial function by reducing the production of mitochondrial reactive oxygen species in a rat model of cardiac arrest. J Cardiovasc Pharmacol Ther 20:330-341

45. Otterbein LE, Otterbein SL, Ifedigbo E, Liu F, Morse DE, Fearns C et al (2003) MKK3 mitogen-activated protein kinase pathway mediates carbon monoxide-induced protection against oxidant-induced lung injury. Am J Pathol 163:2555-2563

46. Nuhn P, Mitkus T, Ceyhan GO, Kunzli BM, Bergmann F, Fischer L et al (2013) Heme oxygenase 1-generated carbon monoxide and biliverdin attenuate the course of experimental necrotizing pancreatitis. Pancreas 42:265-271

47. Wang X, Qin W, Qiu X, Cao J, Liu D, Sun B (2014) A novel role of exogenous carbon monoxide on protecting cardiac function and improving survival against sepsis via mitochondrial energetic metabolism pathway. Int J Biol Sci 10:777-788

48. Foresti R, Green CJ, Motterlini R (2004) Generation of bile pigments by haem oxygenase: a refined cellular strategy in response to stressful insults. Biochem Soc Symp 71:177-192

49. Ben-Amotz R, Bonagura J, Velayutham M, Hamlin R, Burns P, Adin C (2014) Intraperitoneal bilirubin administration decreases infarct area in a rat coronary ischemia/reperfusion model. Front Physiol 5:53 
50. Kvam E, Hejmadi V, Ryter S, Pourzand C, Tyrrell RM (2000) Heme oxygenase activity causes transient hypersensitivity to oxidative ultraviolet $A$ radiation that depends on release of iron from heme. Free Radic Biol Med 28:1191-1196

51. Hurttila H, Koponen JK, Kansanen E, Jyrkkanen HK, Kivela A, Kylatie R et al (2008) Oxidative stress-inducible lentiviral vectors for gene therapy. Gene Ther 15:1271-1279
52. Yegin ZA, lyidir OT, Demirtas C, Suyani E, Yetkin I, Pasaoglu H et al (2014) The interplay among iron metabolism, endothelium and inflammatory cascade in dysmetabolic disorders. J Endocrinol Invest 38:333-338

\section{Submit your next manuscript to BioMed Central} and take full advantage of:

- Convenient online submission

- Thorough peer review

- No space constraints or color figure charges

- Immediate publication on acceptance

- Inclusion in PubMed, CAS, Scopus and Google Scholar

- Research which is freely available for redistribution

Submit your manuscript at

www.biomedcentral.com/submit

() BioMed Central 